\title{
Evaluation of the neurotoxic effects of ethanol on the cerebellar and cortical neurospheres isolated from E14 mouse embryo
}

\author{
E14 fare embriyosundan izole edilen serebellar ve kortikal nörosferler üzerine etanol'ün \\ nörotoksik etkisinin değerlendirilmesi
}

\author{
Nilesh Kumar Mitra ${ }^{1}$, Kanakeswary Krishnan ${ }^{2}$, Chong Chung Hiong ${ }^{2}$, Yen Nee Ding ${ }^{2}$, \\ Hsiao Lung Eddie ${ }^{2}$, Archana Sikarwar ${ }^{1}$
}

\begin{abstract}
Objectives: Ethanol exposure during pregnancy has toxic effects on the neural stem cells of the developing brain. Differential effects of the alcohol on the neural precursor cells from different regions of the brain have not been established. This study was planned to find out the difference in the morphology of the neurosphere (NS) from the embryonic mouse cortex and cerebellum when exposed to ethanol. The dose of ethanol was comparable to blood alcohol concentration in binge drinking.
\end{abstract}

Materials and methods: The germinal tissues around the lateral ventricle and fourth ventricle of the embryo of pregnant albino mice (E14) were dissected out. Primary cultures were plated using adequate density of cells in media hormone mix (MHM) and growth factors. After 48 hours, ethanol was added to the cultures (low dose $=80$ $\mathrm{mg} / \mathrm{dl}$; high dose $=400 \mathrm{mg} / \mathrm{dl}$ ). NS from different groups were analyzed using phase-contrast microscopy, Trypan blue exclusion assay and immunostaining with 4'-6-Diamidino-2-phenylindol (DAPI).

Results: With low dose ethanol treatment, the mean area of cortical neurospheres was reduced by $6.9 \%$ whereas that of the cerebellar neurospheres was reduced by $51.2 \%$. The mean count of pyknotic cells increased significantly $(p<0.05)$ in both low and high dose ethanol treatment group compared to control in both cortical and cerebellar culture. Cerebellar culture showed 4-fold-increase in mean pyknotic cells compared to 2.5 -fold-increase in cortical culture, when exposed to ethanol.

Conclusions: Cerebellar neural precursor cells from E14 mouse were more susceptible to the neurotoxic effects of ethanol compared to the cortical ones. J Clin Exp Invest 2012; 3(4): 443-450

Key words: Neural stem cell, alcohol ethyl, in vitro toxicity

\section{ÖZET}

Amaç: Gebelikte etanol maruziyeti, gelişen beyindeki nöral kök hücreler üzerine toksik etkilere sahiptir. Beynin değişik bölgelerindeki nöral öncül hücreler üzerine alkolün farklı etkileri henüz belirlenmemiştir. Bu çalışma fare embriyonik korteks ve serebellumundan alınan nörosferin etanole maruz kaldığında morfolojideki farklılığı araştırmak için planlandı. Etanol dozu aşırı alkol alımındaki kan konsantrasyonuna benzer idi.

Gereç ve yöntem: Gebe albino fare (E14) embriyosunun lateral ventrikül ve dördüncü ventrikülü çevresindeki germinal doku alındı. Primer kültürler, ortam hormon karışımındaki yeterli yoğunluktaki hücreler kullanılarak ekim yapıldı. Kırksekiz saat sonra kültür ortamına etanol (düşük doz = 80 mg/dl; yüksek doz = 400 mg/dl) eklendi. Farklı grupların nörosferleri faz-kontrast mikroskop, triptan mavısı dışlama testi ve 4'-6-Diamidino-2-fenilindol immunoboyama ile analiz edildi.

Bulgular: Düşük doz etanol ile kortikal nörosferde \%6,9 azalma gözlenirken, serebellar nörosferde $\% 51,2$ azalma oldu. Ortalama piknotik hücre sayıları hem düşük hem de yüksek doz etanol uygulanan gruplarda, hem kortikal hem de serebellar kültürlerde, kontrol gruplarına göre anlamlı artış gösterdi $(p<0,05)$. Serebellar kültür etanole maruz bırakıldığı zaman, ortalama piknotik hücre sayısı bakımından 4 kat artış gösterirken, kortikal kültür 2,5 kat artış gösterdi.

Sonuç: E14 farelerden alınan serebellar nöral öncül hücreler, kortikal hücrelere kıyasla etanol'ün nörotoksik etkilerine daha duyarlıdırlar.

Anahtar kelimeler: Nöral kök hücre, etil alkol, in vitro toksisite

\footnotetext{
${ }^{1}$ School of Medicine, International Medical University, Kuala Lumpur, Malaysia

${ }^{2}$ School of Pharmacy, International Medical University, Kuala Lumpur, Malaysia
}

Correspondence: Nilesh Kumar Mitra, Associate Professor, School of Medicine, International Medical University, No. 126, Jalan 19/155B, Bukit Jalil, 57000, Kuala Lumpur, Malaysia; Fax: +60-3-86567229 Email: nilesh59imu@gmail.com 


\section{INTRODUCTION}

Maternal alcoholism and its effects on the offspring are well-known and have been described in the literature since the period of Greek mythology. A common pattern of birth defects in 127 children born to alcoholic mothers was described for the first time by Lemoine et al. ${ }^{1}$ Subsequently the term foetal alcohol syndrome (FAS) was used for the first time by Jones and Smith to describe infants born to alcoholic mothers with growth retardation, characteristic facial features and central nervous system involvement. ${ }^{2}$ Alcohol is a known suppressant of central nervous system (CNS) and alcohol-induced neuronal loss has been found to be region specific. Animal studies found that prenatal alcohol exposure caused a reduction of cerebellar Purkinje cells, cerebral dysgenesis and loss of the cells of the olfactory bulb. ${ }^{3-5}$ Suppression of the function of cerebral cortex was evidenced in neuropsychiatric studies of children with FAS as observation of attention difficulties, reasoning and memory deficit. ${ }^{6}$ Cerebellar dysfunction was observed as reduced motor performance in the rotarod tests of the mice exposed to ethanol prenatally. ${ }^{7}$ In the developing brain, neural progenitor cells differentiate into neurons, astrocytes and oligodendrocytes.

Mouse gestation period consists of 21 days with the neurogenesis of Purkinje cells of cerebellum (E10.5) and neurogenesis of cortical layer V-VI (E13) being completed by 14th day of gestation (E14). ${ }^{8}$ Tissue cultures from the periventricular areas of the forebrain and cerebellum of the embryonic mice showed successful generation of neurospheres in the presence of growth factors. ${ }^{9}$ People with the habit of binge drinking normally have heavy consumption of alcohol in single occasion. Binge drinking is defined as a pattern of alcohol consumption that brings the blood alcohol concentration (BAC) to $0.08 \mathrm{~g} \%$ or above..$^{10}$ Binge exposure of ethanol to the pregnant mice equivalent to BAC twice the legal limits for the human has resulted in brain malformations in the foetus. ${ }^{11}$

Neuroanatomical studies of the foetal brain suggested that distinct regions and specific cell types appeared to be affected by alcohol-induced neuronal loss. Various regions of the developing brain were not found to be uniformly vulnerable to the teratogenic effects of ethanol. ${ }^{12}$ Although ethanol has variable neurotoxic implication in different brain regions, it still contributes to long-lasting changes of brain function. ${ }^{13}$

The objective of this research was to study the difference between the neurospheres culture from the cortical and cerebellar area of the embryonic mouse brain, when exposed to ethanol. The study would determine whether ethanol has different impact on neural stem cells (NSC) of cortical and cerebellar origin. The viability of the neurospheres with the low and high doses of ethanol would also be tested.

\section{MATERIALS AND METHODS}

\section{Making the mouse pregnant}

Male and female Swiss albino mice from the Institute for Medical Research were kept in separate cages under 12 hourly light and dark cycle at the institutional animal holding facility. All the experiments and activities carried out conformed to the institutional Animal Ethics and Research Committee Guidelines. Mating of male and female mice was done when they were 9 weeks old and during the estrous phase of the female mouse. Determination of the estrous phase was done using vaginal smear examination and observation of large cornified squamous cells. The presence of vaginal plug in the female mouse indicated the pregnancy day 0.5 .

\section{Isolation of neural stem cell (NSC)}

At 14 days (E14) of gestation, the pregnant female mouse was euthanized under ether anesthesia and the uteri was removed and transferred to PBSglucose solution under aseptic condition. Repeated washing with PBS was carried out to remove the blood contaminant and isolate the brains of the embryo. The germinal tissues around the lateral ventricle (for cortical NSCs) and posterior aspect of 4th ventricle (for cerebellar NSCs) were dissected out under aseptic condition using a dissecting microscope. The tissues were transferred to $15 \mathrm{~mL}$ round bottom tubes containing $2 \mathrm{~mL}$ of media hormone mix (MHM) that which enabled the tissues to be cultured in vitro.

\section{Cell culture}

The protocol for culture of neural stem cells by Chojnacki and Weiss was followed. ${ }^{14}$ The germinal tissues were transferred to a $15 \mathrm{ml}$ round bottom tube containing MHM. MHM composed of $1 \mathrm{X}$ DMEM/ F12 (1:1); glucose (0.66\% wt/vol); glutamine (2mM); $\mathrm{NaHCO}_{3}$ (14.6mM); HEPES buffer (5 mM); insulin (23 $\mathrm{mg} / \mathrm{mL})$; transferrin $(93 \mathrm{mg} / \mathrm{mL})$; progesterone (19 nM); putrescine (56 nM); and sodium selenite $(21 \mathrm{nM})$. Standard trituration method using a micropipette with 200 micro-liter plastic tip was used to achieve a single cell suspension ${ }^{14}$. The cell suspension was poured through a $40 \mu \mathrm{m}$ strainer. Primary 
cultures were plated using adequate density of cells in MHM and growth factors [epidermal growth factor (EGF) and fibroblast growth factor (FGF), 10ng/mL respectively] at $37^{\circ} \mathrm{C}$ for 2 days. The culture was maintained at $37^{\circ} \mathrm{C}$ in a $\mathrm{CO}_{2}$ incubator. The culture was passaged every 4 to 5 days. Cell count using haemocytometer with Trypan blue stain was carried out. The neurospheres generated from the tertiary culture was subjected to the ethanol treatment.

\section{Ethanol treatment}

The neurosphere culture was centrifuged at $200 x \mathrm{xg}$ for 10 minutes, supernatant was removed and cell suspension was prepared in total $5 \mathrm{~mL}$ solution (2 $\mathrm{mL}$ cell suspension, MHM and GFs). The cortical and cerebellar neurosphere cultures of third passage (P3) were treated with two concentrations of ethanol for 96 hours. Ethanol was added to two experimental groups of both types of neurosphere cultures and the cultures were incubated at $37^{\circ} \mathrm{C}$ in a $\mathrm{CO}_{2}$ incubator. The control group of culture was treated with normal saline. The experimental groups of culture were treated with low and high doses of ethanol. The change of MHM solution containing ethanol and addition of growth factors were done on alternate days. Ethanol was added to the cultures according to the experimental group condition (low dose $=80 \mathrm{mg} / \mathrm{dl}$; high dose $=400 \mathrm{mg} / \mathrm{dl}$. After 96 hours, neurospheres were analysed for dead cell count using Trypan blue exclusion assay. The pyknotic cells were identified by 4'-6-Diamidino-2-phenylindol (DAPI) stain. Ninety-six hours of ethanol treatment was a short term exposure which simulated binge drinking. Blood alcohol concentration for binge drinking in human was $0.08 \mathrm{~g}$ percent which was equivalent to $80 \mathrm{mg} / 100 \mathrm{~mL}$ or $17.4 \mathrm{mmol} / \mathrm{L}$. ${ }^{10}$ This concentration was used as the low dose ethanol treatment in this study. For high dose ethanol treatment, a concentration of $400 \mathrm{mg} / 100 \mathrm{~mL}$ or 87 $\mathrm{mmol} / \mathrm{L}$ was used, which was equivalent to $0.40 \mathrm{~g}$ percent of BAC. The high dose of ethanol concentration was equivalent to the accepted lethal dose $50\left(\mathrm{LD}_{50}\right)$ of ethanol in adult human.

\section{Qualitative/Quantitative analysis of neurospheres}

After 96 hours of ethanol exposure, photomicrographs of both cortical and cerebellar NSC cultures were captured using an inverted microscope to observe the morphological changes in the neurospheres. After the photomicrographs of the neurospheres were captured under 200X magnification, the area of the neurospheres was measured with the NIS-elements suite, imaging software. Ten neurospheres selected randomly from each treatment group in cortical and cerebellar cultures were selected and the mean area of neurospheres was calculated for each group.

\section{Dead cell count using Trypan blue exclusion assay}

The ethanol treated cortical and cerebellar neurospheres were dissociated to single cell suspension using trituration method and transferred into a 15 $\mathrm{mL}$ tube and centrifuged at $200 \mathrm{~g}$ for 10 minutes. The supernatant was removed and the cell pellet was suspended in $1 \mathrm{~mL}$ PBS. The dead cell concentration was determined using a haemocytometer with Trypan blue exclusion assay. Trypan blue distinguished between the viable and non-viable cells. Viable cells had intact cell membrane which was able to exclude a series of stains, including Trypan blue. The non-viable cells absorbed the dye and stained blue. Under the light microscope, the viable cells appeared phase-bright. Viable cells in the four large corner squares (each corner square was made up of 16 small squares) were counted and the cell count per $\mathrm{mL}$ of the culture was determined using the formula:

Number of cells per $\mathrm{mL}=$ Mean count per square $\mathrm{x}$ dilution factor $\mathrm{x} 10^{4}$.

\section{Quantification of pyknotic cells using DAPI}

The neurospheres in all the treatment groups of both cortical and cerebellar culture were dissociated into single cell suspension using trituration method. The cells were fixed with $4 \%$ paraformaldehyde followed by staining with $0.1 \%$ DAPI for 30 minutes. The pyknotic cells stained with DAPI were viewed under fluorescence microscope and photomicrographs were captured for further analysis. The number of pyknotic cells in a field of $150 \times 150$ square micron was counted from the photomicrographs using the NIS-elements software and compared groupwise.

\section{Statistical analysis}

SPSS for Windows software version 17.0 was used in the statistical analysis. The mean area of the neurospheres and the mean count of pyknotic cells per sq $\mathrm{mm}$ of cell smear in the treatment groups from cortical and cerebellar culture were subjected to Kruskal-Wallis Test to find out any significant intergroup difference among the three treatment groups. The significance level was determined as $p<0.05$. 


\section{RESULTS}

\section{Qualitative analysis of untreated neurospheres}

The culture of the saline treated control groups showed neurospheres containing free floating clus- ters of NSCs (1A and 1B of Figure 1). Compared to the cortical neurospheres, the cerebellar neurospheres (1B of Figure 1) were more compact.
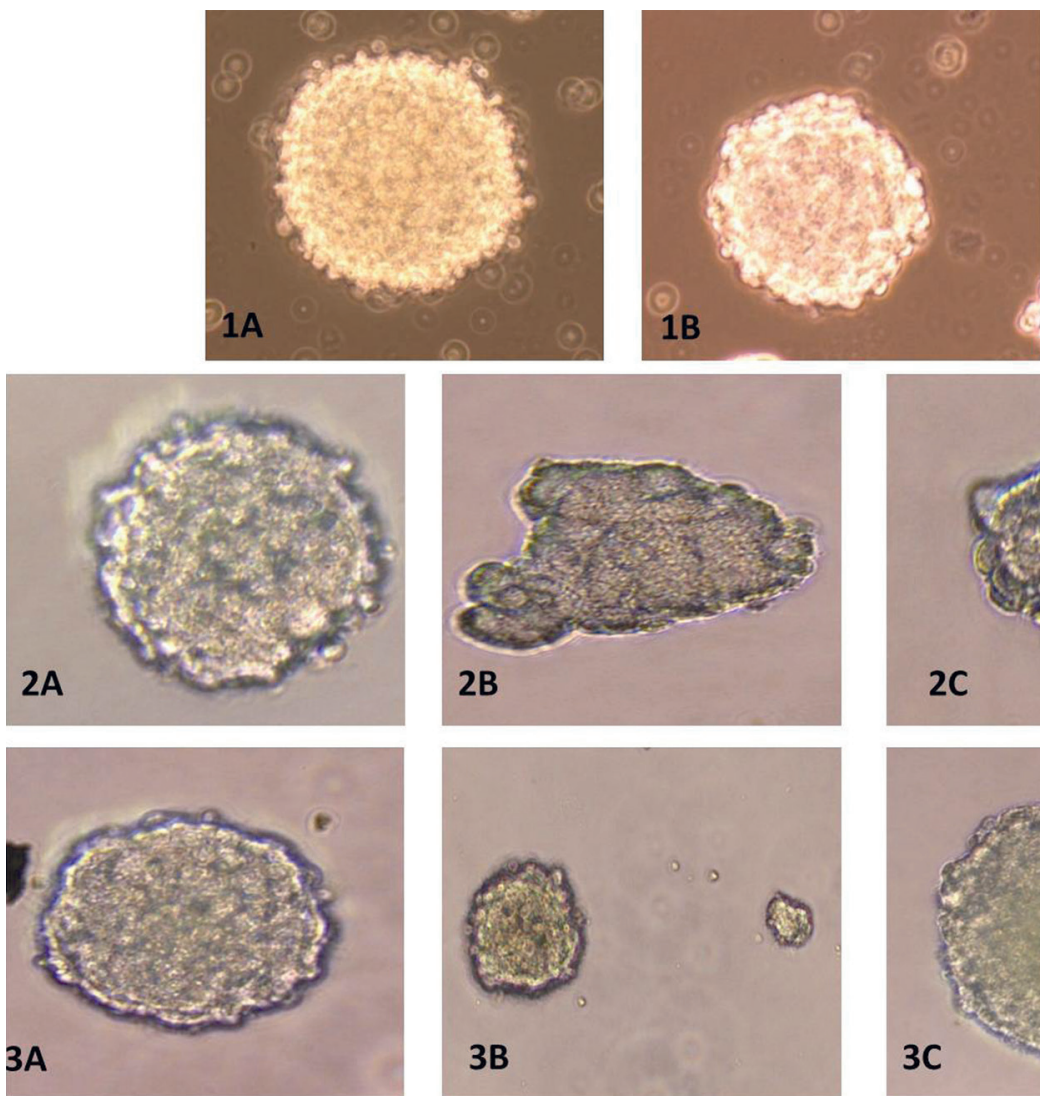

\section{a. Cortical neurospheres}

The ethanol-exposed neurospheres were decreased in size and irregular in shape as compared to the control group ( $2 \mathrm{~B}$ and $2 \mathrm{C}$ of Figure 1). The peripheral rim was not clearly visible and the shape of neurosphere was distorted in both low and high dose ethanol treated groups. The higher the concentration of ethanol, the neurospheres were more disorganised in their structure.

\section{b. Cerebellar neurospheres}

The neurospheres in low (3B of Figure 1) and high ( $3 C$ of Figure 1 ) dose ethanol-treated groups showed irregular edges and dark coloured centre. A few of the cerebellar neurospheres treated with high dose ethanol were larger in diameter compared to the control and low dose ethanol treated group. The cerebellar neurospheres of the low dose ethanol treated group showed the smallest neurosphere amongst all the treatment groups.
Figure 1. Phase contrast photomicrograph of neurospheres in different treatment groups of cortical and cerebellar neural stem cell culture after 96 hours of treatment. 1A. Control group cortical culture, 1B. Control group cerebellar culture, 2A. Control group cortical culture, 2B. Low dose ethanol treatment of cortical culture, 2C. High dose ethanol treatment of cortical culture, 3A. Control group cerebellar culture, 3B. Low dose ethanol treatment of cerebellar culture, 3C. High dose ethanol treatment of cerebellar culture. (200X)

\section{C}

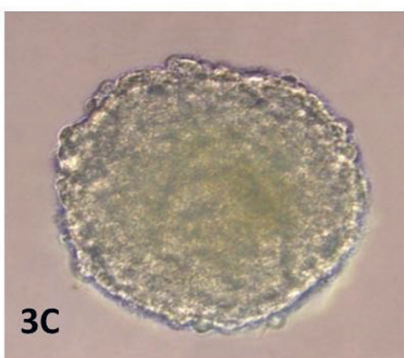

Figure 2 illustrates the bar chart showing the mean area of neurospheres in different treatment groups after 96 hours of ethanol treatment. With low dose ethanol treatment, the mean area of the cerebral cortical neurospheres was reduced by $6.9 \%$ whereas those of cerebellar neurospheres were reduced by $51.2 \%$. High dose ethanol treatment reduced the mean area of cerebral cortical neurospheres by $20.6 \%$ but increased the mean area of cerebellar neurospheres by $12.3 \%$. Although increased in size, cerebellar neurospheres in high dose ethanol treated group showed non-viable cells in the centre. The Kruskal-Wallis test showed significant difference $(p<0.05)$ between the area of neurospheres of three treatment groups only in cerebellar culture.

The mean percentage of non-viable cells dissociated from the cortical and cerebellar neurospheres in the control, low and high dose ethanol treatment groups are shown in Figure 3. In cortical neurosphere culture treated with ethanol, $56.7 \%$ were 
dead when exposed to low dose ethanol and $58.3 \%$ of the cells were dead in high dose ethanol treated group. A total of $66.7 \%$ dead cells were found in cerebellar neurosphere culture treated with low dose ethanol whereas in high dose ethanol treated group, almost all the cells were dead.
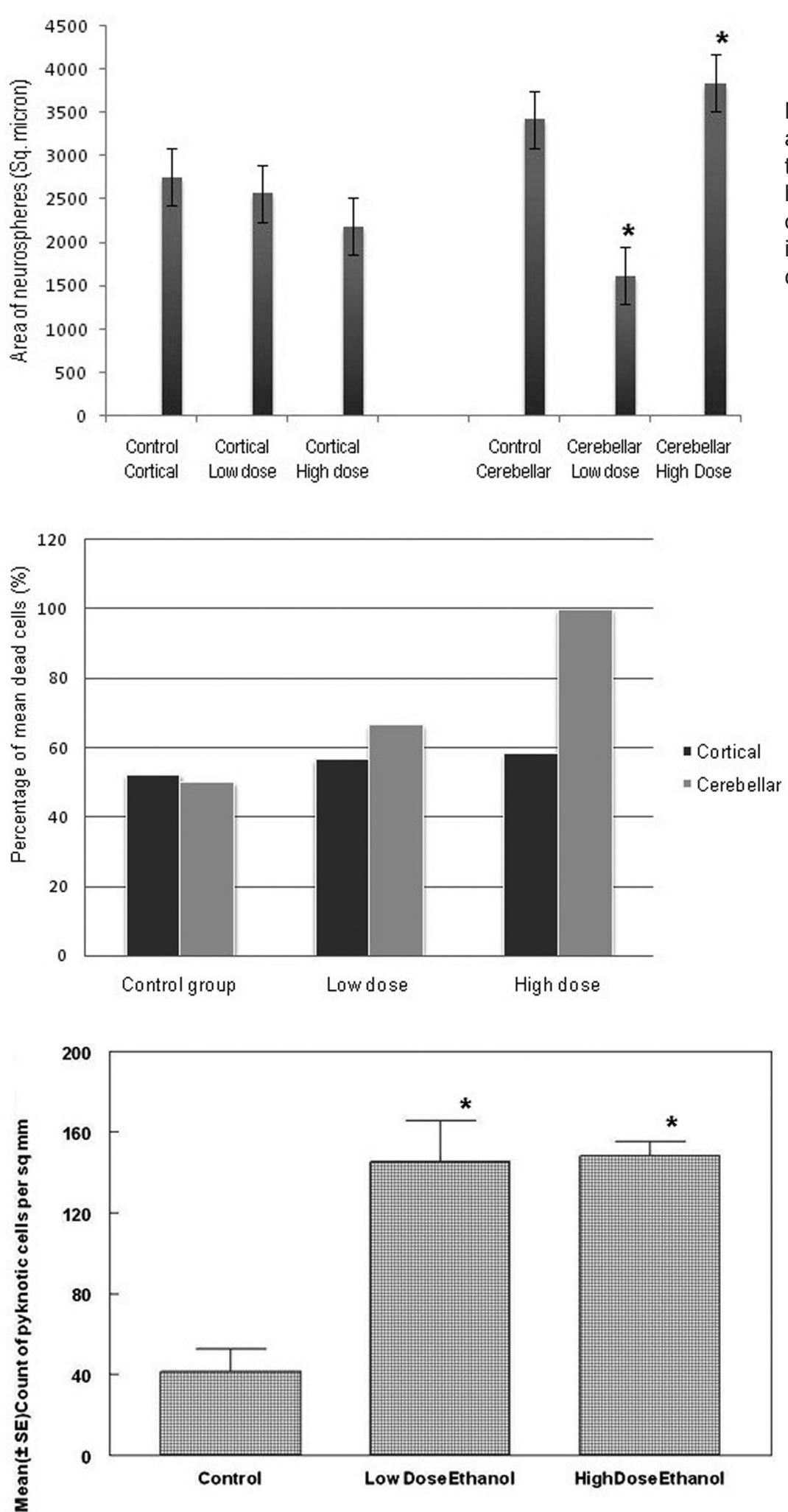

Figure 2. Bar chart showing the mean area of neurospheres ( \pm SE) in different treatment groups of cortical and cerebellar neural stem cell culture after 96 hours of treatment. $\left({ }^{*}\right)$ indicated the group showing significant difference compared to the control. (Kruskall-Wallis test, $\mathrm{p}<0.05$ ).

Figure 3: Bar chart showing the mean percentage of dead cells in Trypan Blue exclusion assay in different treatment groups of cortical and cerebellar neural stem cell culture after 96 hours of treatment.

Figure 4. Bar chart showing the mean count of pyknotic cells ( \pm SE) per sq. $\mathrm{mm}$ of smear in different treatment groups of cortical culture after 96 hours of treatment. $\left({ }^{*}\right)$ indicated group showing significant difference compared to the control. (Kruskal-Wallis test followed by Posthoc test showing intergroup difference, $p<0.05$ ) 


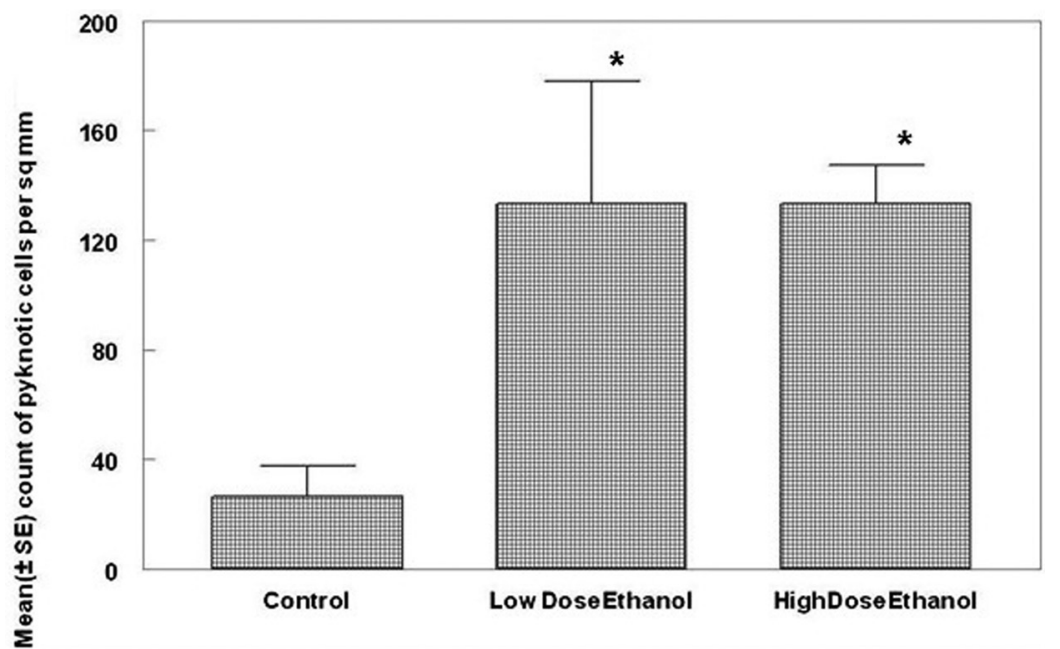

Figure 5. Bar chart showing the mean count of pyknotic cells ( \pm SE) per sq. $\mathrm{mm}$ of smear in different treatment groups of cerebellar culture after 96 hours of treatment. $\left(^{*}\right)$ indicated group showing significant difference compared to the control. (Kruskal-Wallis test followed by Posthoct test showing intergroup difference, $p<0.05$ )
Three flasks each of cortical and cerebellar cultures were selected from the control, low dose and high dose ethanol treatment groups. The mean pyknotic cell count in a rectangular $150 \mu \mathrm{m} \times 150 \mu \mathrm{m}$ area of the cell smear was computed into mean pyknotic cell count per square $\mathrm{mm}$ of the cell smear and compared groupwise. Statistically significant difference $(p<0.05)$ was observed in the mean pyknotic cell count among the experimental groups in cortical culture, with control group showing the lowest mean pyknotic cell count (Figure 4). In comparison to control group, a statistically significant increase $(p<0.05)$ in mean pyknotic cell count of 2.5 and 2.6 fold was observed in low and high dose ethanol treated groups respectively. In fact, high dose ethanol treatment group had the highest mean pyknotic cell count among the different groups of cortical cell culture. For cerebellar culture (Figure 5), a statistically significant difference $(p<0.05)$ was observed in mean pyknotic cell count among the experimental groups, with control group (mean pyknotic cells 27 per $\mathrm{mm}^{2}$ ) showing the lowest count. In comparison to control group, a statistically significant increase $(p<0.05)$ in mean pyknotic cell count of 4 fold was found in both low dose (mean pyknotic cells 133 per $\mathrm{mm}^{2}$ ) and high dose ethanol treated groups (mean pyknotic cells 133 per $\mathrm{mm}^{2}$ ).

\section{DISCUSSION}

The NSCs isolated from the respective embryonic brain areas, aggregated to form the neurospheres which has a ball-like structure with heterogeneous cluster of cells. This observation was observed in saline treated control groups in both cortical and cerebellar culture. Neurospheres formed were free floating with a round or oval shape with regular peripheral rim. Cerebellar neurospheres had close packed appearance compared to the cortical ones. This was due to the presence of granule cells of cerebellar origin, the most abundant precursor cells compared to the other brain regions. ${ }^{15}$ The changes in the morphology of neurospheres in ethanol treated groups were prominently observed when compared with the control group. In ethanol treated cortical culture, the size of the neurospheres was reduced and the reduction was dose dependent. This phenomenon showed that ethanol produced alteration in the proliferation of neural precursor cells, with high dose ethanol treated group being the most affected. A study by Anthony et al. $(2008)^{16}$ showed similar phenomenon with dose dependent effect on the E14 dorsal root ganglia neural stem cells (DRG-NSCs) with shorter ethanol treatment (44 hours). The neurospheres in high dose ethanol treated group were distorted in shape which might be due to the occurrence of apoptotic event. Low dose ethanol treatment $(17.4 \mathrm{mmol} / \mathrm{L})$ produced relatively more damage to the cerebellar NSC culture compared to the cortical NSC culture in the parameters of non-viable cells in the Trypan blue assay as well as count of mean pyknotic cells. However, high dose ethanol treatment $(87 \mathrm{mmol} / \mathrm{L})$ of cerebellar NSC culture caused an increase in the neurosphere size. The increased size of the cerebellar neurospheres was probably due to a preliminary phase of increased proliferation induced by the ethanol. However both the Trypan blue assay and the pyknotic cell count confirmed higher numbers of dead cells in the high dose ethanol treated cerebellar culture. Studies on murine animal models (other than cerebellar region) showed that increased proliferation of precursor cells acted as a compensatory mechanism for ethanol neurotoxicity event. ${ }^{17,18}$

After 96 hours of low dose ethanol treatment, $8.5 \%$ increase in the dead cell count was observed 
per $\mathrm{mL}$ of cortical neurosphere culture. Similar increase in dead cells was $11.7 \%$ in high dose ethanol exposure. Thus the percentage of dead cells from the cerebral cortical culture increased with increased ethanol concentration. The pyknotic cell count using DAPI stain was used by previous studies to determine the apoptotic cell death of neural stem cells. ${ }^{19,20}$ This study showed that ethanol treated culture of both cortical and cerebellar neural precursor cells had higher pyknotic cell count compared to the control group. Ethanol was able to cause pyknosis of the neural stem cells characterized by DNA fragmentation and condensation resulting in apoptotic cell death. ${ }^{21}$ Thus the survival of progenitor cells decreased prominently upon exposure to ethanol.

The neural precursor cells of the cerebellar neurospheres were found to be more susceptible to damage compared to the similar cells of the cerebral cortex when exposed to neurotoxic effect of the alcohol. Exposure to low dose ethanol concentration for 96 hours caused an increase of $33.3 \%$ of dead cells in the cerebellar culture compared to the saline treated control. High dose ethanol treatment increased the percentage of dead cells to $100 \%$ showing appreciable dose-dependent effect of ethanol on the neural precursor cells of the cerebellum. Cerebellum seemed to be more susceptible to ethanol neurotoxicity compared to the cerebral cortex. This study suggested that transient high dose ethanol consumption during early pregnancy would affect the survival of cerebellar neurons resulting in loss of neurons and arrested hindbrain development.

\section{Conclusion}

There was observable difference between the neurosphere culture from the cerebral cortex and the cerebellum when exposed to ethanol, with cerebellar neural precursor cells being more susceptible to neurotoxic effect of the ethanol compared those of the cortex.

\section{Acknowledgements}

The authors would like to thank the Research and Ethics Committee of International Medical University, Malaysia for the grant to carry out this research project.

\section{REFERENCES}

1. Lemoine $P$, Harousseau H, Borteyru JP, Menuet JC. Children of alcoholic parents-observed anomalies: discussion of 127 cases. Ther Drug Monit 2003;25 (2):132-6.
2. Jones KL, Smith DW. Recognition of the fetal alcohol syndrome in early infancy. Lancet 1973; 302 (7836): 999-1001.

3. Chen WJ, Parnell SE, West JR. Neonatal alcohol and nicotine exposure limits brain growth and depletes cerebellar Purkinje cells. Alcohol 1998;15(1):33-41.

4. Coulter CL, Leech RW, Schaefer GB, Scheithauer BW, Brumback RA. Midline cerebral dysgenesis, dysfunction of the hypothalamic-pituitary axis, and fetal alcohol effects. Arch Neurol 1993;50 (7):771-5.

5. Chen WJ, Parnell SE, West JR. Effects of alcohol and nicotine on developing olfactory bulb: loss of mitral cells and alterations in neurotransmitter levels. Alcohol Clin Exp Res 1999;23(1):18-25.

6. Streissguth AP and O'Malley K. Neuropsychiatric implications and long-term consequences of fetal alcohol spectrum disorders. Semin Clin Neuropsychiatry 2000; 5 (3): 177-90.

7. Cebolla AM, Cheron G, Hourez R, Bearzatto B, Dan $B$, Servais $L$. Effects of maternal alcohol consumption during breastfeeding on motor and cerebellar Purkinje cells behavior in mice. Neurosci Lett 2009;455 (1):4-7.

8. Finlay BL, Darlington RB. Linked regularities in the development and evolution of mammalian brains. Science 1995; 268(5217):1578-84.

9. Klein C, Butt SJ, Machold RP, Johnson JE, Fishell G. Cerebellum- and forebrain-derived stem cells possess intrinsic regional character. Development 2005;132(20):4497-508.

10. National Institute of Alcohol Abuse Alcoholism. NIAAA Council Approves Definition of Binge Drinking. NIAAA newsletter[serialonline]2004, http://pubs.niaaa.nih. gov/publications/newsletter/winter2004/newsletter_ number3.pdf

11. Sulik KK, Lauder JM, Dehart DB. Brain malformations in prenatal mice following acute maternal ethanol administration. Int J Dev Neurosc 1984;2(3): 203-14.

12. Chen WJ, Maier SE, Parnell SE, West JR. Alcohol and the developing brain: neuroanatomical studies. Alcohol Res Health 2003; 27 (2): 174-80.

13. Goodlett CR, Horn KH. Mechanisms of alcoholinduced damage to the developing nervous system. Alcohol Res Health 2001;25 (3):175-84.

14. Chojnacki A, Weiss S. Production of neurons, astrocytes and oligodendrocytes from mammalian CNS stem cells. Nat Protoc 2008; 3(6):935-40.

15. Lee A, Kessler JD, Read TA et al. Isolation of neural stem cells from the postnatal cerebellum. Nat Neurosci 2005;8(6):723-9.

16. Anthony B, Zhou FC, Ogawa T, Goodlett CR, Ruiz J. Alcohol exposure alters cell cycle and apoptotoic events during early neurulation. Alcohol Alcohol 2008;43(3):261-73.

17. Zharkovsky T, Kaasik A, Jaako K, Zharkovsky A. Neurodegeneration and production of the new cells in the dentate gyrus of juvenile rat hippocampus after a single administration of ethanol. Brain Res 2003;978(12):115-23. 
18. Aberg E, Hofstetter CP, Olson L, Brené S. Moderate ethanol consumption increases hippocampal cell proliferation and neurogenesis in the adult mouse. Int $\mathrm{J}$ Neuropsychopharmacol 2005;8(4):557-67.

19. Diaz B, Serna F, De Pablo F, de la Rosa EJ. In vivo regulation of cell death by embryonic (pro) insulin and the insulin receptor during early retinal neurogenesis. Development 2000;127(8):1641-9.
20. Kuan CY, Schloemer AJ, Lu A et al. Hypoxia-ischemia induces DNA synthesis without cell proliferation in dying neurons in adult rodent brain. J Neurosci 2004; 24(47):10763-72.

21. Cherian PP, Schenker S, Henderson GI. Ethanol-mediated DNA damage and PARP-1 apoptotic responses in cultured fetal cortical neurons. Alcohol Clin Exp Res 2008;32(11):1884-92. 